جامعـة نيويورك أبـوظـبي 世 NYU $\mid$ ABU DHABI

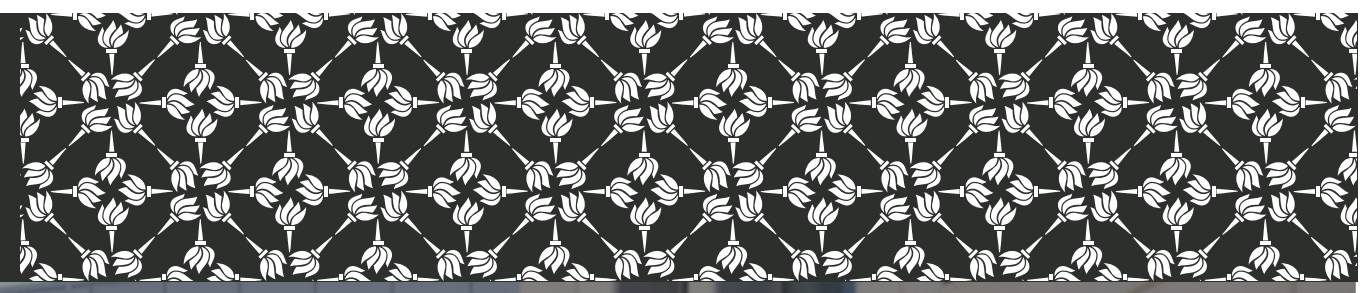

\title{
The Economics of the Manila Galleon
}

\author{
Javier Mejia
}

Working Paper \# 0023

January 2019 


\title{
The Economics of the Manila Galleon*
}

\author{
Javier Mejia ${ }^{\dagger}$
}

\begin{abstract}
The Manila Galleon was a commercial route that existed from 1565 to 1815 . It connected Asia and America through the Pacific Ocean. It was a fundamental step in the history of globalization. The objective of this essay is to offer an economic framework to interpret the existing evidence on the Manila Galleon. Based on this framework, the essay identifies that the Manila Galleon was only possible thanks to the coincidence of a quite singular set of international circumstances and favorable market conditions at the local level. Additionally, the essay explores the experience of New Granada as a way to highlight the large asymmetry in the role and impact of the Manila Galleon trade across regions.
\end{abstract}

JEL: D85; J13; O11; O14; O33; O41.

Keywords: Manila Galleon; Trade History; Globalization; Silver; Philippines; Mexico; New Granada.

*This essay was prepared for the Academic-Cultural Initiative of the Pacific Alliance, Philippines, and Spain Embassies in Bangkok, together with Thammasat University, UNESCO and the Ministry of Foreign Affairs of Thailand, "Transpacific Connectivity through the Manila Galleon: Southeast Asia, the Pacific Coast of the Americas and Spain"

${ }^{\dagger}$ New York University Abu Dhabi. Email:javiermejia@nyu.edu. Website http://javiermejia.strikingly.com/ 


\section{Introduction}

The emergence of the Manila Galleon was an essential episode in trade history. It represented the first time in which Asia, America, and Europe were connected by trade. In that sense, it can be interpreted as a fundamental step in the birth of globalization.

Consequently to its historical importance, historians have extensively studied the Manila Galleon (e.g. Schurz, 1918; Chaunu, 1960; TePaske, 1983, Fish, 2011; Bonialian, 2012, Giraldez, 2015). Thanks to this, we have a good knowledge of the business practices, the techniques, and the cultural consequences related to the Manila Galleon. However, economists, in contrast to historians, have payed much less attention to it 1 This has led to deficient areas in the understanding of the relationship between the Manila Galleon and broader elements of the economic environment, such as technological progress, market integration, international division of labor, and regional growth disparities.

The objective of this essay is to offer an economic framework to interpret the existing historical evidence on the Manila Galleon. Hence, I expect to reach two distinct audiences. On the one hand, I intend to increase the exposure of the Manila Galleon to economists interested in the origins of globalization. On the other hand, I expect that historians working on the early Pacific trade could find useful insights on the economic perspective presented here at the time of interpreting their sources.

I start the essay with a brief description of the basic facts of the Manila Galleon in Section 2. I analyze the forces behind its emergence and decline in sections 3 and 4 . In this sections, I describe how the Manila Galleon resulted from the coincidence of a rather singular set of international circumstances and favorable market conditions at the local level. Section 5 explores the nuances that the Manila Galleon brought to global integration. This section uses the experience of New Granada to highlight the asymmetric functions that the different regions played. In particular, I develop the idea that there were three types of players in the Manila Galleon trade: keys, intermediates, and satellites. Finally, in Section 6, I conclude by arguing that the economic impact of the Manila Galleon was ultimately minor at the global level, but that its role as precursor of global integration should not be dismissed.

\footnotetext{
${ }^{1}$ An important exception on this regard is the literature on the monetary consequences of China's silver imports (e.g. Von Glahn, 1996b, Irigoin, 2009, 2018)
} 


\section{Context}

\subsection{Trade pattern}

The Manila Galleon was the commercial route that existed from 1565 to 1815 between Asia and America through the Pacific Ocean. It connected, as main ports, Manila and Acapulco. The Manila Galleon was deeply interrelated to the American-European trade. In fact, from the European perspective, the Manila Galleon is frequently interpreted as a phenomenon fostered by the Spanish Crown, which consisted in taking advantage of its imperial territories for the acquisition of highly appreciated (in European markets) East Asian goods. This, as an alternative to the land routes through Central Asia and the one that surrounded Africa.

If we consider the Manila Galleon as the European trade initiative described above $2^{2}$ it is relevant to notice that it was not a centralized activity guided by the determinations of a single agent. It consisted of, at least, two phases. In the first phase was Carrera de Indias, which was under the monopoly of European merchants in Seville/Cadiz. It encompassed all the trade between Spain and its American colonies. $3^{3}$ The West Indies Fleet was the main element of Carrera de Indias. Second, there was Carrera de Islas Poniente, of a smaller scale in terms of the number and tonnage of the ships, as well as the volume and value of the exchanges (Yuste, 1987) ${ }^{4}$ It was based on the Acapulco-Manila connection. Carrera de Islas Poniente was carried out, mainly, by merchants from Mexico City and Manila. Trade in Carrera de Islas Poniente was quite regular, being practically uninterrupted for 250 years.

Focusing on the connection Acapulco-Manila, it is worthwhile to briefly describe the complexities that the commercial endeavor implied. First, merchants in both ports

\footnotetext{
${ }^{2}$ As I discuss in more detail in Section 3.1.4 this position underestimates some non-European forces that are fundamental to understand the Manila Galleon.

${ }^{3}$ To have an idea of the figures involved in Carrera de Indias, consider a couple of examples. The fleet commanded by Lieutenant General Don Carlos Reggio, who left Veracruz for Spain in 1760, brought products worth 9,811,245 current pesos. The fleet commanded by the squadron leader Don Agustin Indiaguer Borja sailed in 1765 to Spain with a cargo of 15,785,452 pesos (Silva Herzog, 1956).

${ }^{4}$ Some authors, including in their calculations smuggling, claim that the commercial volume of Carrera de Poniente during the 16th and 17th century was similar to that of Carrera de Indias. Bold accounts speak about 12,000,000 pesos (Flynn and Giraldez, 1995). Conservative figures such as those of Von Humboldt (1811), on the other hand, speak of 2,000,000 pesos; even so, this is more than what was allowed by the Crown. In any case, intermediate estimates, such as those of Barrett (1990), who speak on average of 5,500,000 pesos a year, seem reasonable.
} 
gathered goods from several different origins. In Acapulco arrived: silver, cochineal for dyes, seeds, sweet potato, tobacco, chickpea, chocolate and cocoa, watermelon, vine and fig trees from the Americas; wine barrels and olive oil came from Spain; and swords with their daggers, garrisons, knobs, curbs and spurs from Germany, France, and Italy. The European goods arrived from Seville to Veracruz and were transported by land to Acapulco. The composition of the cargo was fairly stable, being about $80 \%$ goods from America and 20\% European (Sales Colín, 2000). The cargo from Manila had a more unstable and diverse composition, due to the smaller size of the American market (Yuste, 1987). However, most of the time, the cargo included goods from all over Asia. From China, jade, wax, gunpowder, and silk fabrics and products (e.g. stockings, handkerchiefs, bedspreads and tablecloths); from the Middle East, rugs and camel wool; from India, pieces of cotton, and amber; from Japan, fans, drawers, chests, folding screens, scribes and porcelain; and from South East Asia, spices (mainly cloves, pepper and cinnamon) (Sales Colín, 1996).

Therefore, the Manila Galleon was a specialized international exchange, mainly of an inter-industrial nature. This is similar to the pattern predicted by the classic models of international trade, in which countries specialize in the activities in which they have comparative advantages. As I describe later, transport costs were so high, that importing goods with similar local substitutes was not rational. Additionally, the protectionist policies in place at the moment made it almost impossible for "non-exotic" imports to compete in the markets with domestic products.

\subsection{Regulations and voyage}

Despite the administrative independence of Carrera de Indias and Carrera de Islas Ponientes, the Spanish Crown was a synchronizing institution between them. The Crown established a quite strict regulation over the trade activity, limiting the number of merchants allowed to participate, defining the timing of the voyages, and restricting their routes. Eventually, the Crown intervened directly with companies of its own property and management-I explore this in more detail in Section 4 .

Departing from Acapulco, the voyage consisted in crossing a fairly uncharted ocean for approximately four months per trip. $5^{5}$ The living conditions in the interior of the

\footnotetext{
${ }^{5}$ Only two ships a year were allowed to sail. The cargo of these ships could not exceed 300 tons of weight (Boxer, 2017). Smuggling, nevertheless, was a regular activity in this trade route.
} 
ships were precarious ${ }^{6}$ Moreover, the imperial conflicts of Spain brought additional risks to the trip. The Pacific Ocean was full of English and Dutch corsairs, who, sponsored by their States, lurked commercial ships that intended to arrive in Manila. For instance, the voyages were interrupted between 1646 and 1648 because of the Dutch war of Independence (Sales Colín, 2000). This, with out mentioning the hostile Japanese ships abundant near the coast of the Philippines (Barker, 2009).

The return trip followed the Kuroshio current. Once in Acapulco, a fraction of the Asian cargo stayed in America, remaining a certain percentage in present-day Mexico and re-exporting the rest (frequently, via smuggling), mainly to other parts of Spanish America. Most of the Asian goods were reexported to the Viceroyalty of Peru-where aristocratic families demanded Asian goods-but a considerable fraction ended up in more distant markets, such as Buenos Aires (Bonialian, 2014). The remaining products were taken to Veracruz by mule and then shipped to the port of Seville/Cadiz.77

\section{Emergence}

\subsection{Macro forces}

\subsubsection{Geopolitical situation}

To begin with, the global political panorama of the mid-sixteenth century was ideal for the emergence of a trade route between Asia and Europe through the West lead by Spaniards.

First, the ancient trade routes through the Levant were highly constrained 8 . Islamic empires-i.e. Ottomans, Safavid, and Mongolians-were in control of the Middle East. The hostilities between these empires and the Christian Europe-in particular between the Ottoman Empire and the Habsburgs-were at a high peak. Meanwhile in Europe, the Italian city-states, which played an essential role in Mediterranean trade for centuries,

\footnotetext{
${ }^{6}$ The famous Italian traveler, Giovanni Francesco Gemelli Careri, describes quite vividly his experience traveling from the Philippines to New Spain in one of the ships of the Manila Galleon. He recalls the trip as a nightmare plagued of diseases, hunger, and dirt (Careri, 1700).

${ }^{7}$ The fraction of Asian goods that ended in Europe was rather small. Between $75 \%$ and $90 \%$ of the cargo departing from America towards Spain was gold and silver (Silva Herzog, 1956)

${ }^{8}$ The Levantine trade did not disappear completely. However, its magnitude reduced quite significantly (see Pach, 1987, Christ, 2012)
} 
were in political and economic decline. France and northern Europe, despite their increasing maritime power, were immersed in the Wars of Religion (De Vries, 1976).

On the other hand, the disputes between Portugal-which had a practical monopoly on the maritime trade with Asia (Paine, 2014)-and Spain-which was in expansion both geographically and economically to take advantage of the discovery of the New World-were finished when Felipe II assumed the throne of both kingdoms. Thus, he could exert control over strategic territories for the commerce between Asia and Europe, such as the Philippines and all the American continent discovered until the moment, in addition to European domains that played important functions in this trade networks (Ocampo Suárez-Valdés and Peribáñez Caveda, 2009). An essential aspect for understanding the importance of the Spanish imperial possessions is the role of mercantilism as a policy constraint.

\subsubsection{The role of mercantilism}

Mercantilism was a profound feature of the economic system of the period. It could be characterized by a fever for noble metals and a widespread commercial culture. Nations competed to enrich themselves through the accumulation of gold and silver, based on favorable trade balances. This was the main principle of international economic policy. Paradoxically with the commercial boom, mercantilism brought extreme barriers to international trade, making necessary the existence of good political relations for the success of trade between nations.9

The initial stage of the Manila Galleon precisely coincided with the rise of mercantilism. In such context, the great extension of "the empire on which the sun never sets" became fundamental. According to Chaunu (1960), Spain achieved control over more than half the population of the Western Hemisphere between 1535 and 1540 . Looking quickly at the possessions of Spain in Europe, we find the entire Iberian Peninsula, including Portugal; the kingdom of Naples (present south of Italy along with Sardinia, Sicily, and Malta); Central East France; the Duchy of Milan, and the Spanish Netherlands (current Belgium, Luxembourg and the Netherlands).

While the tariff barriers to domestic colonial trade were quite high ${ }^{10}$ they were

\footnotetext{
${ }^{9}$ The study of mercantilism as a type of society with a particular institutional structure has recently earned renew attention in economics (see Congleton and Lee, 2009: Drelichman, 2005).

${ }_{10}^{10}$ Silva Herzog (1956), citing Bernardo Ward (a renowned Spanish-Irish economist of the 18th century), argues that the tax burdens between Spain and its colonies was between $100 \%$ and $200 \%$.
} 
not as high as those governing between territories without political-administrative ties, implying that a wide imperial extension allowed the relative cheapening of "local" products-i.e. those produced within the empire. Addtionally, the potential economies of scale that propitiate large markets gave a comparative advantage to Spain for the re-export of American and Asian goods in Europe. After all, as Wallerstein (2011) mentions, this trade, more than international, corresponded to an interregional trade 11

\subsubsection{Technological progress}

The expansion of mercantilism was not only driven by cultural and ideological forces; the advances in maritime technology also played an important role. During the 15th and 16th centuries, the European exploration of the oceans and the scientific improvements in areas like mathematics led to a much better understanding of long-distance navigation. A good expression of this process was the increasing accuracy of world maps. From Juan de la Cosa's map (1500)-the first map known that incorporated America-to Gerardus Mercator's map (1569)-which became the basis of navigation for the centuries to come-there is a significant improve in extension and precision, in particular of the Pacific Rim (see maps 1 and 2).

$$
\text { [Maps } 1 \text { and } 2 \text { here] }
$$

The Manila Galleon was a concrete result of the advances in maritime technology. To being with, Spaniards had an advantage in the knowledge of the Pacific Rim. The trips of Magallan, Lopez de Legazpi, and de Urdaneta offered concrete routes to the connect America and the Philippines to the Spaniards. In addition, the capacity of the Spanish ships increased significantly during this period, being the ships used in the Manila Galleon at the frontier of this technology. To have an idea of this, consider that La Santa Maria, the largest ship of the first Columbus trip to America, had about 17 meters long on deck, 100 tons burden, and could carry about 40 people (Phillips and Phillips, 1993). Meanwhile, La Concepcion, one of the ships used in the Manila Galleon in the 17th century was 49 meters long, with a burden of about 2,000 tons, and the capacity to carry a crew between 300 and 500 people (Mathers and Shaw, 1993).

\footnotetext{
${ }^{11}$ This is a similar argument to the one that Price (1989) develops for the British commercial expansion of the 17 th and 18 th century.
} 


\subsubsection{The importance of American silver}

Asian markets were not particularly interested in European goods (Paine, 2014). The main force behind the risky Manila Galleon endeavor was the demand for American goods, in particular the appetite for silver in China.

During the 15th and 16th centuries, the Chinese monetary system, based for hundreds of years on paper money, made a transition to a silver-based one. Specifically, since the 1570 s, the only acceptable currency for paying taxes was silver. Eventually, silver would be the dominant currency even in non-fiscal related transactions (see Von Glahn, 1996a). China represented about a quarter of the world's population during the period and had one of the largest taxing systems of the world (see Feuerwerker, 1995; Huang et al., 1998, Sng and Moriguchi, 2014). Thus, the domestic demand for silver in China boosted in the late 16th and early 17th centuries (see Figure 1). Interestingly, the price of silver in China was already high by the mid-1500s in comparative terms. The ratio of silver-gold exchange (units of gold to one of silver) was $1 / 6$ in China, while 1/8 in India, 1/10 in Persia, and 1/12 in Europe (Giraldez, 2015).12

[Figure 11 here]

The price gap made most of the silver in the world flow towards China. Map 3 shows this pattern between 1650-1750. The Manila Galleon played a crucial role in this global phenomenon, as the largest silver mines in the world were being discovered in Spanish America. Between 1500 and 1800, close to 150,000 tons of silver were produced in Latin America, over $80 \%$ of world production (Flynn and Giraldez, 1995).

$$
[\text { Map } 3 \text { here] }
$$

Spaniards realized quite early that exporting silver to China was a great commercial opportunity. By 1565, the first Spanish settlers of Philippines were demanding silver to be send from New Spain in order to be trade for Chinese goods (Kueh, 2014). In a couple of decades silver became the largest export from Latin America to the Philippines. The most recent estimates indicate that, on average, 75 metric tons of silver were transported annually from Acapulco to Manila (Bonialian, 2012). Silver

\footnotetext{
${ }^{12}$ It is important to mention that some authors, including Von Glahn (1996b), argue that there was not a price gap between Europe and China in the silver market before the 16th century. Nevertheless, the actual flows of silver indicate otherwise.
} 
was sent in the form of reales and as artistic or religious objects (Sales Colín, 2000). Eventually, the silver coin minted in America became a widely accepted currency in East Asia (Valdés, 2003).

\subsection{Micro motives}

Despite the convenient macro environment, the Manila Galleon was a highly complex activity and it is not obvious that it would have emerged spontaneously. For a better understanding of the incentives that drove its existence, let me explore the individuals involved directly on it and the circumstances in which they developed their businesses.

As I introduced in Section 2, the Manila Galleon was a decentralized enterprise. There were three large groups of entrepreneurs behind it. All of them were motivated by the same drive: the high profits of this trade route. ${ }^{13}$ Nevertheless, each of them faced several different constraints.

\subsubsection{European merchants in Seville}

You would expect that under the mercantilist environment, Spaniards would have dominated the commercial enterprises, at least in Carrera de Indias. However, in most of the Iberian Peninsula, as in other parts of Europe, it used to be considered unworthy to carry out activities labeled as "low, vile, and mechanical", among which there were certain types of trade. Moreover, the social status structure, in the region, privileged the ownership of land and the possesion of nobility titles. The latter implied to demonstrate that for several generations your family was Christian and had not been involved in the unworthy activities described above. Thus, trade was not the most popular occupation within Spaniards. This ideology was maintained for several centuries, giving rise to what Hobsbawn calls "Iberian feudal capitalism", where the bourgeoisie tried to defect from business activities to become nobles (Ocampo Suárez-Valdés and Peribáñez Caveda, 2009). Having said that, Pike (1965) argues that the values of Seville's elites in the

\footnotetext{
${ }^{13}$ There are several isolated references on the rates of return of the Manila Galleon trade. Chuan (1973) argues that it ranged between $100 \%$ and $1000 \%$ for the 17 th century. Careri (1700) argues that he earned a 300\% return. Flynn and Giráldez (1999) consider a 10\% yearly return for the Spanish Crown. Kueh (2014) does one of the most systematic explorations of the issue and considers that a $30 \%$ profit margin should have been normal for the mid-18th century. In any case, for a pre-modern context in which there was almost not economic growth at all, these figures indicate an exceptionally profitable business.
} 
16th century rapidly changed to embrace trade. Moreover, he sees no evidence of real stigma towards merchants from the 16th century onward.

In any case, a significant part of those carrying trade activities in Seville/Cadiz were Europeans from areas with ancient commercial traditions. This is corroborated by a massive migration of individuals from the Republic of Genoa, Flanders, and Portugal to Seville during the early 16th century. The fortune of these migrants was quite heterogeneous. Some of them were able to have access to a license to trade with America, while others had to conform with inserting in a labor market that saturated soon. Curiously, of those who prospered, several acquired nobility titles, effectively inserting themselves in the local aristocratic elites (Fernández, 2001).

\subsubsection{New Spaniard merchants in Acapulco}

The share of the Asian cargo that remained in America was mostly sold in the Acapulco fair. Merchants from different regions of New Spain participated with small amounts of money compared with those coming from Mexico City. The large merchants from Mexico City sent every year several millions of pesos for purchases in the fair (Yuste, 1987). This gave them the power to impose prices and, more importantly, to control the contracts and the regulation of the trade with Manila (Bjork, 1998).

Part of the business that the Mexico City merchants captured was the provision of goods to the government of Manila. The Spanish Crown had to support its presence in the Philippines, including administrative staff, military, and priests. In fact, most of the management of the Manila government was coordinated from New Spain. Thus, the Crown, through the New Spain government, established a contractual system that used the private sector to supply food and other goods to the Philippine government (Sales Colín, 2000).

Nevertheless, the Mexico City merchants were constrained by the interests of European merchants. For instance, due to the pressure of the commercial elite of Seville, in 1593, the Crown limited the freight value of the galleons cargoes to 250.000 pesos

for Manila and to 500.000 pesos for Acapulco (Boxer, 2017). As I develop in Section 6 . this is a signal of a complex hierarchical structure underlying the Manila Galleon. 


\subsubsection{Chinese merchants in Manila}

In Manila, most of the commercial business were controlled by the Chinese community.14 Chinese merchants-usually called Sangley-had settled in Manila several decades before the arrival of Spaniards, and were already connected to the most important commercial networks of the region (Chia, 2006, Boxer, 2017). However, the trade with America generated a massive migration from China, in particular from Fujian. Hence, the chinese population in Manila passed from 150 in 1564 to 30,000 in 1603. They agglomerated in a certain area of the city-eventually known as the Parian-forming a cohesive communities and an active entrepreneurial environment (Hu-Dehart, 2015).

This community, by 1689, had a population that performed more than 60 different occupations. It included artisans, manufacturers, service providers, and vendors of all kinds. A large fraction of these activities intended to attend the demand for Asian goods from American and European markets.

The Parian was destroyed by the Manila Government several times during the 17th century, and its population was expelled. Different types of conflicts between the Spanish groups in Manila and the Chinese were the motives of this actions. The reconstruction of the Parian was, apparently, always related to the pressure of American merchants, who require the goods and services provided by the Chinese population (Borao, 1998).

\section{Decline}

The last voyage of the Manila Galleon took place in 1815. The signs of decline, however, started much earlier.

\subsection{The arrival of modernity and the end of mercantilism}

To begin with, from the European perspective, the main reason to trade with Asia through America was the constraints attached to the most direct routes in the 16th century. By the 19th century, these constraints had almost disappeared.

\footnotetext{
${ }^{14}$ Several other communities were involved in trade activities in Manila. For instance, after the Spanish ban on European shipping at Manila, Armenians and Indians played active roles as merchants. Most of their business consisted in camouflaging exports to Britain (Bhattacharya, 2008).
} 
By the early 19th century, the macro context had completely changed. European empires had controlled key locations that guaranteed stable commercial flows from Asia to Europe westwards. Moreover, the demand for Asian products had been progressively substituted by European production. The British Industrial Revolution brought textiles, porcelains, spices, and silks at low prices. Additionally, Britain also became the new front runner in maritime innovations. Overall, the British Empire had a clear comparative advantage to supply the global demand for the goods that used to be traded in the Manila Galleon, both directly or through their colonies.

The British expansion also had an effect on the economic policy of the Spanish Empire. It is possible to trace this to the navio de permiso, which resulted from the Peace of Utrecht. This was an authorization of the Spanish Crown for the British to send a ship of 500 tons each year to trade with the Spanish colonies of South America. In practice, the true size of the trade established with Great Britain exceeded the 500 ton limit (Díaz-Trechuelo, 2003). In 1750, England renounced the navío de permiso, but continued similar commercial activities through illegal methods, reaching quite significant figures for the first decade of the 19th century (Goebel, 1938). The navío de permiso represented the end of the monopoly of the Seville/Cadiz merchants over the American imports in Europe.

This was followed by the decline of mercantilism, and the consolidation of laissezfaire ideas. Liberalism changed the attitudes of policy makers and public opinion towards the encouragement of free trade. This liberal ideas would be materialized on the Bourbon reforms, but they were preceded by decades of pressure from different groups. A particular focus of concern were the protectionist trade policies between New Spain and the Philippines. For many in Spain, the profits from the Manila Galleon remained in the hands of the elites of Mexico City.

These pressures would lead, in 1785, to the creation of the Royal Company of the Philippines, which was born with the idea of centralizing trade with the Philippines in Spain. The Company dealt directly with the negotiation of goods in Asian ports, and the sale of those goods in the American territories, seeking also to establish a direct route between Manila and Seville around Cape Horn (Yuste, 2007).

Despite some early success that lead them to participate in new markets in China, the Royal Company of the Philippines failed in the long-term (Permanyer-Ugartemendia, 2014). Its major weakness was its incapacity to compete with British trade networks. The Company closed in 1834. Despite its short existence, it destroyed the Mexican 
monopoly over the Manila trade, reducing even more the profitability of the Manila Galleon.

\subsection{The decay in silver prices}

The high demand for silver in China during the 17th century returned to pre-boom levels before the end of the century. However, the productivity gains in mining in the Spanish America were enough to keep exports of silver to Asia profitable for several decades (Flynn and Giraldez, 1995).

Nevertheless, the arbitrage incentives would eventually disappear. The constant flow of silver from all over the world to China kept pressure on its price, erasing any gap with international markets. Hence, gold-silver exchange rates (silver units for a unit of gold) passed from 9 to 14 in India (between 1575 and 1750), and from 9 to 15 in China (between 1500 and 1750) (Broadberry and Gupta, 2006). This had concrete effects on the Manila Galleon. Already by 1650, the America silver exports to China were decreasing, reaching less than $3 \%$ of the total production (see Figure 2).

[Figure 2 here]

The reduction of silver prices in Asian markets was not exclusively related to arbitrage. The gigantic American production had an aggregate effect and pushed the price down all over the world. Even in Europe the relative price of silver fell, going from 11 to 15 (between 1500 and 1750). The trend deepened in the 19th century with a global process of demonetization, which drastically reduced the demand for silver. This

process began in Europe, but eventually reached Asia at the end of the century (Slade, $1982)$.

In such, the main force of the exceptionally high profits of the Manila Galleon slowly disappeared.

\subsection{American Independence}

Finally, the Manila Galleon was affected by the revolutions in the American colonies. To begin with, the war and the posterior institutional turmoil in Latin America brought a profound economic crisis that lasted several decades (de la Escosura, 2009). This affected 
the demand for Asian products. In addition, there was a significant shift in the economic and political power. On the one hand, the merchant elites, and, in general, the larger networks that supported commercial activity changed with Independence. The very valuable connections that Mexico City merchants had with the New Spain government for supplying Manila government disappeared. Moreover, the new Republican governments of Mexico considered the Manila Galleon a form of colonial exploitation (Dillon, 1951).

More structurally, even in more favorable economic conditions, the interruption of diplomatic relations between Latin American colonies and the Spanish Empire represented a profound political conflict for a stable trade connection between Manilawhich remained part of the empire until the Spanish-American War-and Latin America.

\section{Regional asymmetries. The experience of New Granada}

In order to highlight the regional asymmetries involved in the Manila Galleon, I will explore the experience of New Granada. New Granada was a territory that comprised most of current Colombia, Ecuador, and the southern part of Central America (see Map 4). The precise spatial and political definition of New Granada changed significantly over the colonial period. Thus, for simplicity, I will focus on the current territory of Colombia.

$$
\text { [Map } 4 \text { here] }
$$

Based on its location, New Granada should have played an important role in the American trade between Europe and Asia. Excluding New Spain, it was the largest Spanish colony with exposure both to the Atlantic and the Pacific oceans. Moreover, it had some of the shortest paths connecting both oceans. Additionally, it was an intermediate point between the different Spanish colonies in America.

Nonetheless, the role played by New Granada in the Manila Galleon was minuscule. New Granada was not a significant seller or buyer of products from Asia. New Granada's labor and capital did not participate either in the Manila Galleon. Its connection to

the Manila Galleon was limited to the import of small quantities of luxury Asian goods, in particular, silk products that were reexported from Venezuela (Bonialian, 2012).

Three major elements kept New Granada disconnected from the Manila Galleon. 
First, the geographic conditions of New Granada were unfavorable for international trade. To begin with, despite its apparent disposal, the Pacific coast in New Granada was rather isolated and could not be used as a commercial platform. The territory of current Colombia is characterized by a mountainous system that crosses from South to North. This system is part of Los Andes mountain range. Los Andes-plus the tropical jungle that covers most of the non mountainous areas-represented a gigantic barrier to the transport of goods and people to the Pacific Coast, in particular, to those coming from the Atlantic Coast-which is on the other side of Los Andes. In fact, this lead to an almost complete depopulation of the the Pacific Coast. Map 5 shows that no permanent Spanish settlement was founded until 1600.

$$
\text { [Map 5 here] }
$$

Moreover, unlike its composition in other parts of the continent, Los Andes divides into three different mountain ranges in Colombia. These three mountain ranges are separated by the course of two rivers, El Magdalena and El Cauca, bringing additional barriers to human activity.

During the colonial period, the mountain ranges represented a natural obstacle for communication, not only between the coasts and the rest of the country, but also between the sub-regions of the Andean zone itself, where most of the population was settled. First, the steepness of the soil limited the type of transport technology available. For instance, the use of carriages was limited to urban areas. Goods and people moving between regions had to be transported in mules' or humans' backs (see Illustration 1). Second, the mountainous composition of the territory increase the harm of weather. To make matters worse, altitude variations made average temperature change significantly within short distances, affecting the health of travelers and animals. Furthermore, in the general context of a tropical country, the periodic rainy seasons deteriorated the paths, because of the high concentration of organic material in the mountain soil. As if that were not enough, the rains had also effects on the flow of rivers. Thus, for entire seasons (both in summer and winter) it was impossible to navigate them.

$$
\text { [Illustrations } 1 \text { and } 2 \text { here] }
$$

The situation did not improve with technological advances. As Table 1 shows, even in the first part of the 19th century, internal transport costs in New Granada more than 
doubled the ones in Bolivia, which was the second country with the highest transport costs in Latin America.

$$
\text { [Table } 1 \text { here] }
$$

In total, the geographical conditions of New Granada represented serious restrictions for international trade. In particular, they did not allow the emergence of an infrastructure capable to support the trade that came with the Manila Galleon in New Granada's Pacific coast. This kept the cost of imports high enough for avoiding any relevant access to Asian products.

The second reason that kept New Granada disconnected from the Manila Galleon was the purchasing power of the population. New Granada was a poor economy, even in the Latin-American context. Figure 3 shows that, during the 18th century, the real wage in New Granada was lower than in the rest of the region. This, without considering the current territory of Argentina, which was the wealthiest colony of South America.

[Figure 3 here]

Kalmanovitz (2008) and Coatsworth and Taylor (1998) have GDP estimates for several regions of Latin America in the late colonial era. Based on those figures, the conclusions are quite similar. New Granada's GDP per capita was 27 US dollars in 1800. Meanwhile, in Argentina, GDP per capita was 82; in Mexico, 40; in Brazil, 29; and in Peru, 33 .

Therefore, even if Asian goods would managed to overcome the geographical barriers and reach New Granada's markets at competitive prices, they might have not found as many consumers as they did in other places like Mexico, Peru, or Argentina.

Finally, New Granada did not have access to the commodity that fueled the Manila Galleon, silver. New Granada did have a mining sector that grew considerably during the 18th century. However, it was rather small in comparison with the ones in Mexico, Peru, and Brazil. In addition, most of the mining activity was on gold, and not on silver (McFarlane, 2002). Thus, the silver production of New Granada was several dozen times less than the one of Peru or New Spain.

[Figure 4 here] 
If we consider the internal demand for silver and the above mentioned constraints to exports, it is not surprising that the silver from New Granada did not participate in the Manila Galleon.

To sum up, New Granada exemplifies the minor impact of the Manila Galleon at global level. Even a region fairly well-integrated to the Spanish trade circuits, with several economic, cultural, and geopolitical similarities to New Spain, was out of the reach of the American-Asian trade. Slight differences in its geographical and market conditions explain this pattern. Most areas in America faced similar circumstances. Only Peru-thanks to its exceptional silver mines endowment-brought some relevant connectivity to the Manila Galleon. Meanwhile in Asia, the intricate geopolitical environment, in which Spaniards were not able to penetrate effectively, stressed even more the detachment of certain regions. India and Japan, for instance, were connected to the most important East Asian trade networks. However, there is no evidence that their participation in the Manila Galleon had a relevant impact in their economies. In that sense, the idea that the Manila Galleon kept permanently connected America and Asia is inaccurate. Except for New Spain and Manila, most areas of America and Asia hardly noticed the existence of the Manila Galleon.

\section{Concluding remark}

This essay presents an economic framework to interpret the existing evidence on the Manila Galleon. This exercise offers two general conclusions.

First, the Manila Galleon was a highly complex and costly activity that was only possible thanks to the coincidence of a very singular set of circumstances. The high demand for silver in Asia, the extension of the Spanish Empire and its geopolitical leadership, and the particular direction of technological progress at the moment made the connection between Asia an America a highly profitable business. This macro forces aligned with favorable market conditions at local, which allow the emergence of communities able to carry out the activities that the Manila Galleon required.

This conclusion is important in the light of the literature on trade persistence (Mahutga, 2006, Disdier and Head, 2008). There is significant evidence that historical trade flows increase the probability of posterior flows between two places. This persistence could last even for millennia (Barjamovic et al., 2017). Nonetheless, the American-Asian trade did not follow that pattern. Despite the long and sustained trade 
history of the colonial era, it took almost a century after the end of the Manila Galleon to see any significant commercial flow between America and Asia again. Moreover, the new flows did not connect Mexico and the Philippines, but China/Japan and the US. In that sense, this essay gathers evidence on the disappearance of trade routes, the decadence of economic hubs, and the non-persistence of economic activity, in general.

Second, despite the importance of the Manila Galleon as a symbol of globalization, its economic impact was minor, or, at least, fairly contained at local level. In other words, instead of a commercial activity that involved the whole world, the Manila Galleon a was rather limited trade network with significant externalities in a handful of markets and locations. Moreover, there was a large asymmetry in the effects of this trade on the economies of the locations it impacted. More specifically, the Manila Galleon generated three levels of impact.

To begin with, Western Europe and China were the key players on the Manila Galleon. On the one hand, the Spanish Crown defined the institutional framework that shaped the course of the Manila Galleon. This framework intended to preserve Crown's interests. On the other hand, the market demand for silver directed the incentives of every agent involved in the Manila Galleon ventures.

Furthermore, New Spain and the Philippines were intermediate players. Their role was functional to the interest of the key players. However, these regions had some agency to capture rents from the activity. These regions, the commercial elite benefited from the protection and support of the Crown. In addition, the push to the aggregate demand that the commercial flow brought, generated salient economic and urban expansions in cities such as Manila and Acapulco.

Finally, there were satellite players with fairly low levels of engagement on the Manila Galleon. These players had no capacity to extract significant benefits from the American-Asia connection. In his category was most of the world, even economies well-connected in the traditional trade circuits of the intermediate players. A clear example of this was New Granada. Nevertheless, economies that the literature frequently describes as important parts of the Manila Galleon, such as Peru or India, in real terms had minuscules impacts in their economies. Thus, they were closer to satellite players than to intermediate ones.

This second conclusion should be interpreted in the light of the discussion on the origins of globalization (see O'rourke and Williamson, 2002, 2004; Rönnbäck, 2009, De Vries, 2010). The fact that the economic impact of the Manila Galleon was minor 
at global level, does no mean that it must be disregarded as a fundamental event in the history of globalization. Essential aspects of a global economy were born with the Manila Galleon. A good example of this was the global arbitrage and the posterior convergence of prices in the silver market. Similarly, the emergence of real cosmopolitan communities like Manila, which supported the articulation of complex trade networks that expanded through several continents was an primordial symbol of globalization. But the role of this elements is not exclusively symbolic. Some of them supported in an implicit way the expansion of global trade during the 19th century. For instance, the knowledge on the navigation of the Pacific Ocean, or the exposure to foreign manufacturing goods in markets like Latin America, were fundamental in the success of market expansion for the British industrial production.

Therefore, the research on the Manila Galleon should keep growing. Studies expanding to fields that test systematically its effects on aggregate economic performance are crucial. In this regard, quantitative research is particularly needed. The long tradition on archival collection developed by historians offers a huge potential to this line of research. In addition, studies in regions different from Mexico, Manila, Spain, and China would contribute to a better understanding of the global consequences of the Manila Galleon.

\section{References}

Abad, L. A., Davies, E., and Van Zanden, J. L. (2012). Between conquest and independence: Real wages and demographic change in spanish america, 1530-1820. Explorations in Economic History, 49(2):149-166.

Abramitzky, R. (2015). Economics and the modern economic historian. The Journal of Economic History, 75(4):1240-1251.

André, E. and Saffray, C. (1879). Geografía pintoresca de colombia. Grabados editados en París.

Barjamovic, G., Chaney, T., Coşar, K. A., and Hortaçsu, A. (2017). Trade, merchants, and the lost cities of the bronze age. Technical report, National Bureau of Economic Research.

Barker, T. W. (2009). Pulling the spanish out of the 'christian century': Reevaluating spanish-japanese relations during the seventeenth century. Eras, pages 17-37. 
Barrett, W. (1990). The Rise of Merchant Empires. Long Distance Trade in the Early Modern World 1350-1750, volume 1350, chapter World bullion flows, 1450-1800, page 1750. Cambridge University Press.

Bhattacharya, B. (2008). Making money at the blessed place of manila: Armenians in the madras-manila trade in the eighteenth century. Journal of Global History, $3(1): 1-20$.

Bjork, K. (1998). The link that kept the philippines spanish: Mexican merchant interests and the manila trade, 1571-1815. Journal of World History, pages 25-50.

Bonialian, M. A. (2012). El pacífico hispanoamericano: Política y comercio asiático en el imperio español (1680-1784). El Colegio de Mexico AC.

Bonialian, M. A. (2014). China en la América colonial: bienes, mercados, comercio y cultura del consumo desde México hasta Buenos Aires. Instituto Mora.

Borao, J. E. (1998). The massacre of 1603 chinese perception of the spanish in the philippines. Itinerario, 22(1):22-40.

Boxer, C. R. (2017). Plata es sangre: Sidelights on the drain of spanish-american silver in the far east, 1550-1700. In European Entry into the Pacific, pages 209-230. Routledge.

Broadberry, S. and Gupta, B. (2006). The early modern great divergence: wages, prices and economic development in europe and asia, 1500-1800. The Economic History Review, 59(1):2-31.

Careri, G. F. G. (1700). Giro del mondo, volume 4. Nella stamperia di Giuseppe Rosselli.

Chaunu, P. (1960). Les Philippines Et Le Pacifique Des Ibériques (XVIe, XVIIe, XVIIIe Siécles); Introduction Méthodologique Et Indices D'activité. SEVPEN.

Chia, L. (2006). The butcher, the baker, and the carpenter: Chinese sojourners in the spanish philippines and their impact on southern fujian (sixteenth-eighteenth centuries). Journal of the Economic and Social History of the Orient, 49(4):509-534.

Christ, G. (2012). Trading conflicts: Venetian merchants and Mamluk officials in late medieval Alexandria, volume 93. Brill. 
Chuan, H.-S. (1973). Studia Asiatica: Essays in Felicitation of the Seventy-fifth Anniversary of Professor Chen Shouyi, chapter The Chinese silk trade with Spanish America from the Late Ming to the Mid-Ching period. Chinese Materials Center.

Coatsworth, J. H. and Taylor, A. M. (1998). Latin America and the world economy since 1800, volume 2. Harvard Univ David Rockefeller.

Colander, D. (2000). The death of neoclassical economics. Journal of the history of Economic Thought, 22(2):127-143.

Congleton, R. D. and Lee, S. (2009). Efficient mercantilism? revenue-maximizing monopoly policies as ramsey taxation. European Journal of Political Economy, 25(1):102-114.

de la Escosura, L. P. (2009). Lost decades? economic performance in post-independence latin america. Journal of Latin American Studies, 41(2):279-307.

De Vries, J. (1976). The economy of Europe in an age of crisis, 1600-1750. Cambridge University Press.

De Vries, J. (2010). The limits of globalization in the early modern world. The Economic History Review, 63(3):710-733.

Díaz-Trechuelo, L. (2003). La real compañía de filipinas en guipúzcoa. Revista de estudios marítimos del país vasco, 4.

Dillon, R. H. (1951). The last plan to seize the manila galleon. The Pacific Historical Review, pages $123-125$.

Disdier, A.-C. and Head, K. (2008). The puzzling persistence of the distance effect on bilateral trade. The Review of Economics and statistics, 90(1):37-48.

Drelichman, M. (2005). The curse of moctezuma: American silver and the dutch disease. Explorations in Economic History, 42(3):349-380.

Fernández, L. A. (2001). Comercio con américa y títulos de nobleza: Cádiz en el siglo xviii. Cuadernos dieciochistas, (2):109-149.

Feuerwerker, A. (1995). Studies in the economic history of late imperial china. Ann Arbor, Center for Chinese Studies, University of Michigan. 
Fish, S. (2011). The Manila-Acapulco galleons: the treasure ships of the Pacific. With an annotated list of the transpacific galleons 1565-1815. AuthorHouse.

Flynn, D. O. and Giraldez, A. (1995). Arbitrage, china, and world trade in the early modern period. Journal of the Economic and Social History of the Orient/Journal de l'histoire economique et sociale de l'Orient, pages 429-448.

Flynn, D. O. and Giráldez, A. (1999). Pacific Centuries: Pacific and Pacific Rim history since the sixteenth century, chapter Spanish profitability in the Pacific: The Philippines in the sixteenth and seventeenth centuries, pages 23-37.

Giraldez, A. (2015). The Age of Trade: The Manila Galleons and the Dawn of the Global Economy. Rowman \& Littlefield.

Goebel, D. B. (1938). British trade to the spanish colonies, 1796-1823. The American Historical Review, 43(2):288-320.

Hu-Dehart, E. (2015). The manila galleon trade: The forgoteen silk road of the spanish american empire. 1565 - 1815. In Exploring maritime heritage dynamics: Interdependence among maritime cities.

Huang, R. et al. (1998). The ming fiscal administration. The Cambridge History of China, 8(Part 2):144-48.

Irigoin, A. (2009). The end of a silver era: The consequences of the breakdown of the spanish peso standard in china and the united states, 1780s-1850s. Journal of World History, pages 207-243.

Irigoin, A. (2018). Global silver: bullion or specie? supply and demand in the making of the early modern global economy. Economic History Working Papers.

Kalmanovitz, S. (2008). El pib de la nueva granada en 1800: auge colonial, estancamiento republicano. Revista de Economía Institucional, 8(15).

Kueh, J. E. S. (2014). The Manila Chinese: Community, Trade, and Empire, c. 1570-c. 1770. PhD thesis, Georgetown University.

Mahutga, M. C. (2006). The persistence of structural inequality? a network analysis of international trade, 1965-2000. Social Forces, 84(4):1863-1889. 
Margo, R. A. (2018). The integration of economic history into economics. Cliometrica, 12(3):377-406.

Mathers, W. M. and Shaw, N. (1993). Treasure of the Concepción. APA Publications.

McFarlane, A. (2002). Colombia before independence: economy, society, and politics under Bourbon rule, volume 75. Cambridge University Press.

Mejía, J. (2015). The evolution of economic history since 1950: From cliometrics to cliodynamics (la evolución de la historia económica desde 1950: de cliometría hasta cliodinámica). Tiempo \& Economia.

Mejía, J. (2016). Reconstrucción de pib regionales en colombia (1800-2015): una revisión crítica de las fuentes y los métodos. Sociedad y Economía, (30):305-334.

Mokyr, J. (2010). On the supposed decline and fall of economic history. Historically Speaking, 11(2):23-25.

Ocampo Suárez-Valdés, J. C. and Peribáñez Caveda, D. (2009). Historia económica mundial y de España. Universidad de Oviedo.

O'rourke, K. H. and Williamson, J. G. (2002). When did globalisation begin? European Review of Economic History, 6(1):23-50.

O'rourke, K. H. and Williamson, J. G. (2004). Once more: When did globalisation begin? European Review of Economic History, 8(1):109-117.

Pach, Z. P. (1987). Levantine trade routes to hungary 15 th-17th centuries. Acta Historica Academiae Scientiarum Hungaricae, 33(1):57-65.

Paine, L. (2014). The sea and civilization: a maritime history of the world. Atlantic Books Ltd.

Permanyer-Ugartemendia, A. (2014). Opium after the manila galleon: The spanish involvement in the opium economy in east asia (1815-1830). Investigaciones de Historia Económica-Economic History Research, 10(3):155-164.

Phillips, W. D. and Phillips, C. R. (1993). The Worlds of Christopher Columbus. Cambridge University Press.

Pike, R. (1965). The sevillian nobility and trade with the new world in the sixteenth century. Business History Review, 39(4):439-465. 
Pomeranz, K. (2009). The great divergence: China, Europe, and the making of the modern world economy. Princeton University Press.

Price, J. M. (1989). What did merchants do? reflections on british overseas trade, 1660-1790. The journal of economic history, 49(2):267-284.

Rönnbäck, K. (2009). Integration of global commodity markets in the early modern era. European Review of Economic History, 13(1):95-120.

Sales Colín, O. (1996). El movimiento portuario de acapulco: un intento de aproximación (1626-1654). Revista complutense de historia de América, (22):97-97.

Sales Colín, O. (2000). Las cargazones del galeón de la carrera de poniente: primera mitad del siglo xvii. Revista de Historia Economica-Journal of Iberian and Latin American Economic History, 18(3):629-661.

Schurz, W. L. (1918). Mexico, peru, and the manila galleon. Hispanic American Historical Review, pages 389-402.

Silva Herzog, J. (1956). El comercio de méxico durante la época colonial. Homenaje de el Colegio Nacional al doctor Manuel Toussaint, 13:43-73.

Slade, M. E. (1982). Trends in natural-resource commodity prices: an analysis of the time domain. Journal of Environmental Economics and Management, 9(2):122-137.

Sluiter, E. (1998). The Gold and Silver of Spanish America: C. 1572-1648. Bancroft Library, University of California.

Sng, T.-H. and Moriguchi, C. (2014). Asia's little divergence: State capacity in china and japan before 1850. Journal of Economic Growth, 19(4):439-470.

TePaske, J. J. (1983). New world silver, castile, and the philippines, 1590-1800. Precious Metals in the Later Medieval and Early Modern Worlds, pages 425-45.

Valdés, V. (2003). El peso mexicano en el este de asia después del siglo xviii. In Documento presentado en el XI Congreso Internacional de ALADAA, Ciudad de México.

Von Glahn, R. (1996a). Fountain of fortune: money and monetary policy in China, 1000-1700. Univ of California Press. 
Von Glahn, R. (1996b). Myth and reality of china's seventeenth-century monetary crisis. The Journal of Economic History, 56(2):429-454.

Von Humboldt, A. (1811). Political Essay on the Kingdom of New Spain..., volume 1. I. Riley.

Wallerstein, I. (2011). The modern world-system I: Capitalist agriculture and the origins of the European world-economy in the sixteenth century, volume 1. Univ of California Press.

Yuste, C. (1987). Francisco ignacio de yraeta y el comercio transpacífico. Estudios de historia novohispana, 9(009).

Yuste, C. (2007). La percepción del comercio transpacífico y el giro asiático en el pensamiento económico español del siglo xviii. un recuento a partir de los escritos de fray íñigo abbad y lasierra. Martínez-Cano, MP, y Ludlow, L.(Coords.), Historia del pensamiento económico. Del mercantilismo al liberalismo, pages 131-168. 


\section{$7 \quad$ Figures}

Figure 1: Price of silver. Index of coin/silver exchange ratio. Jiangnan. 1527-1712

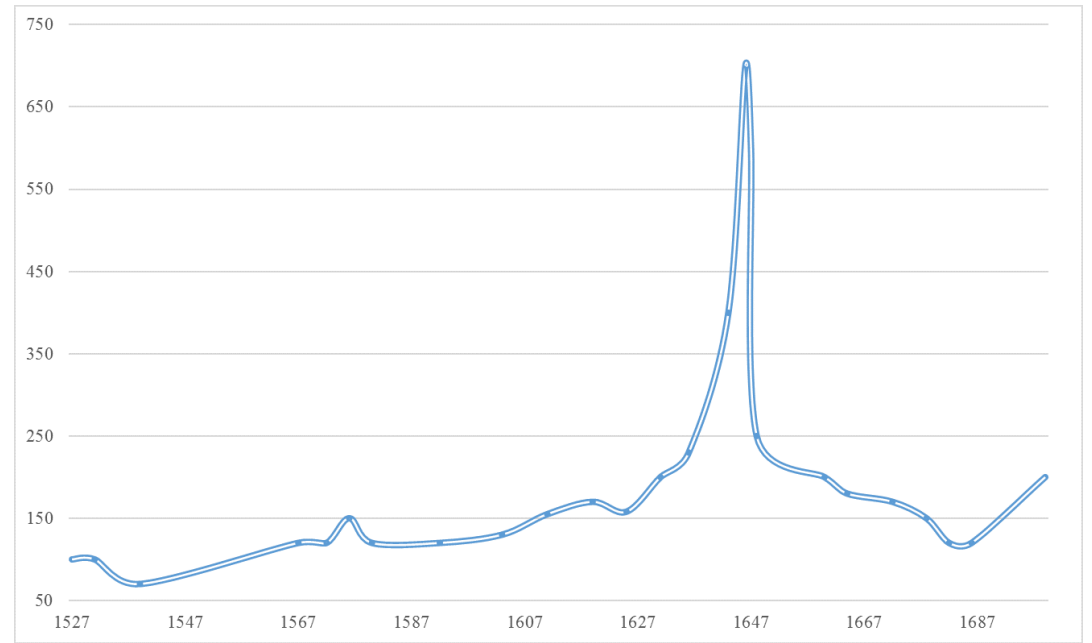

Note: This figure shows the evolution of the index coin/silver exchange ratio in Jiangnan. It is based on Von Glahn (1996b). The frequency of the data varies depending on the sources availability.

Figure 2: Remissions of silver from Spanish America to Manila. Percentage of reported production. 1581-1650

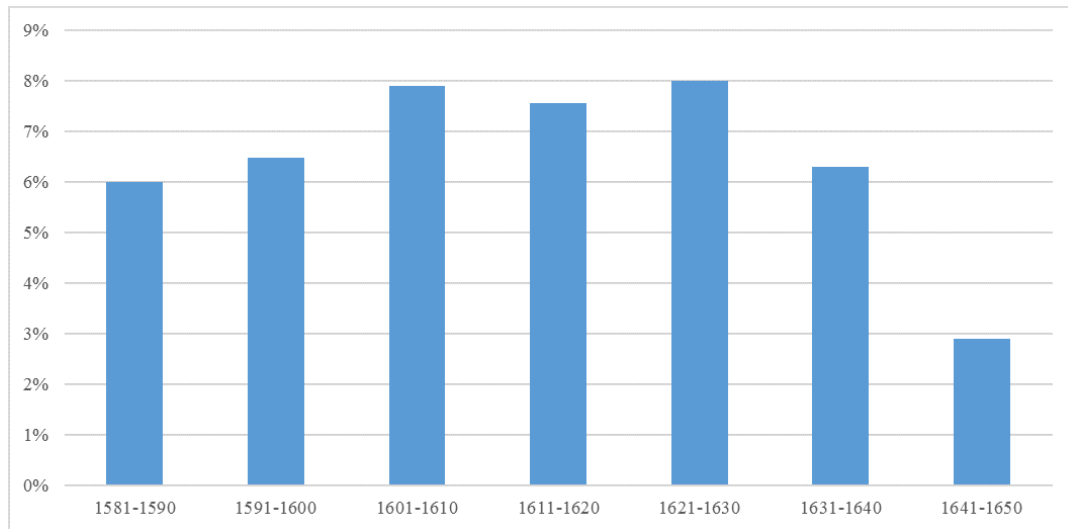

Note: This figure shows the share of silver that was sent to the Philipines from New Spain, Peru, and New Granada. It is based on Sluiter (1998). These figures do not account for illegal trade, which was considerably large. 
Figure 3: Real wages. Bare-bones baskets. Spanish America. 1708-1808

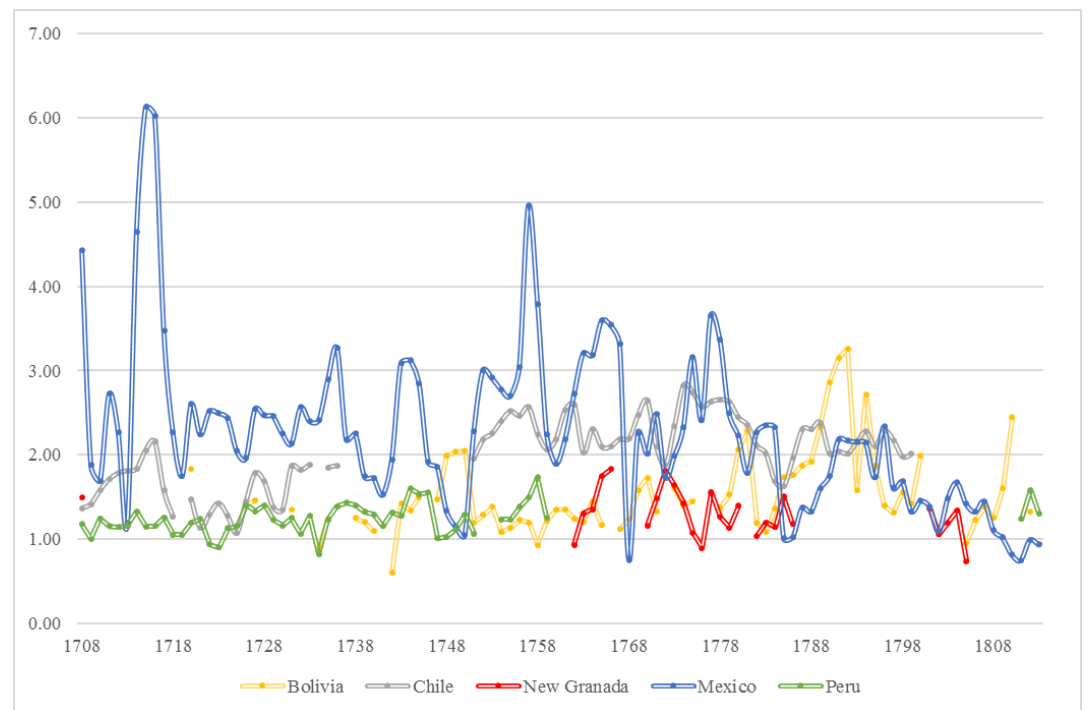

Note: This figure shows the evolution of real wages in Bolivia, Chile, New Granada, Mexico, and Peru in the late colonial era. It is based on Abad et al. (2012).

Figure 4: Silver production. Current pesos. Spanish America. 1581-1650

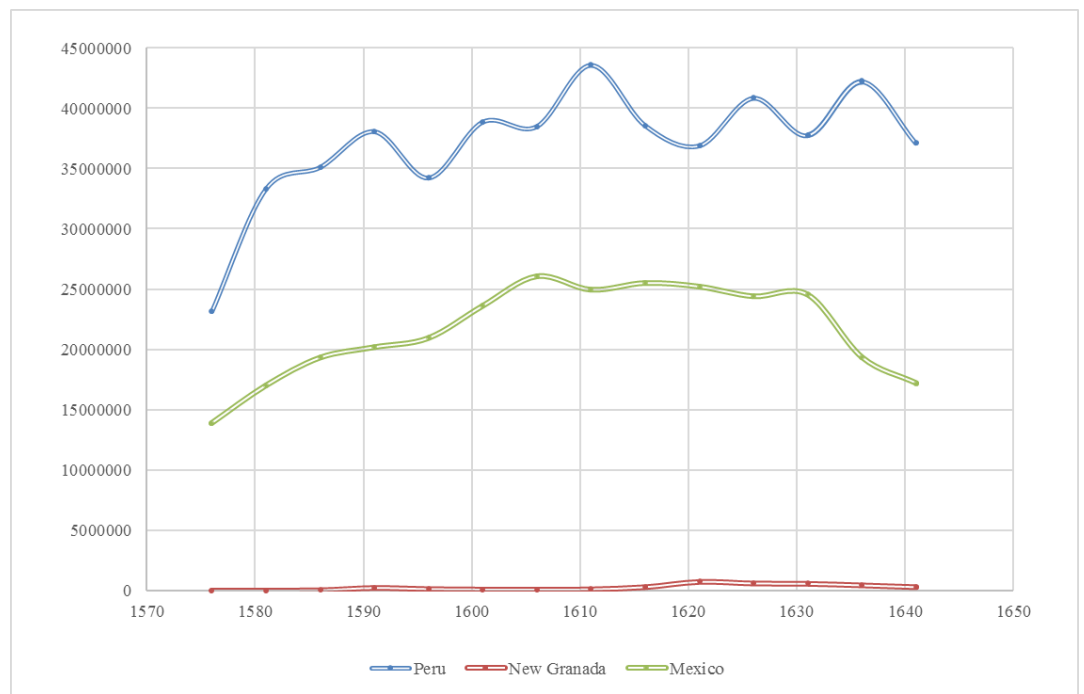

Note: This figure shows the evolution of reported production of silver in Peru, New Granada, an Mexico in the early colonial period. 5-year totals. It is based on Sluiter (1998). These figures do not account for illegal production, which was considerably large. 


\section{Maps}

Map 1: Map of Juan De la Cosa. 1500

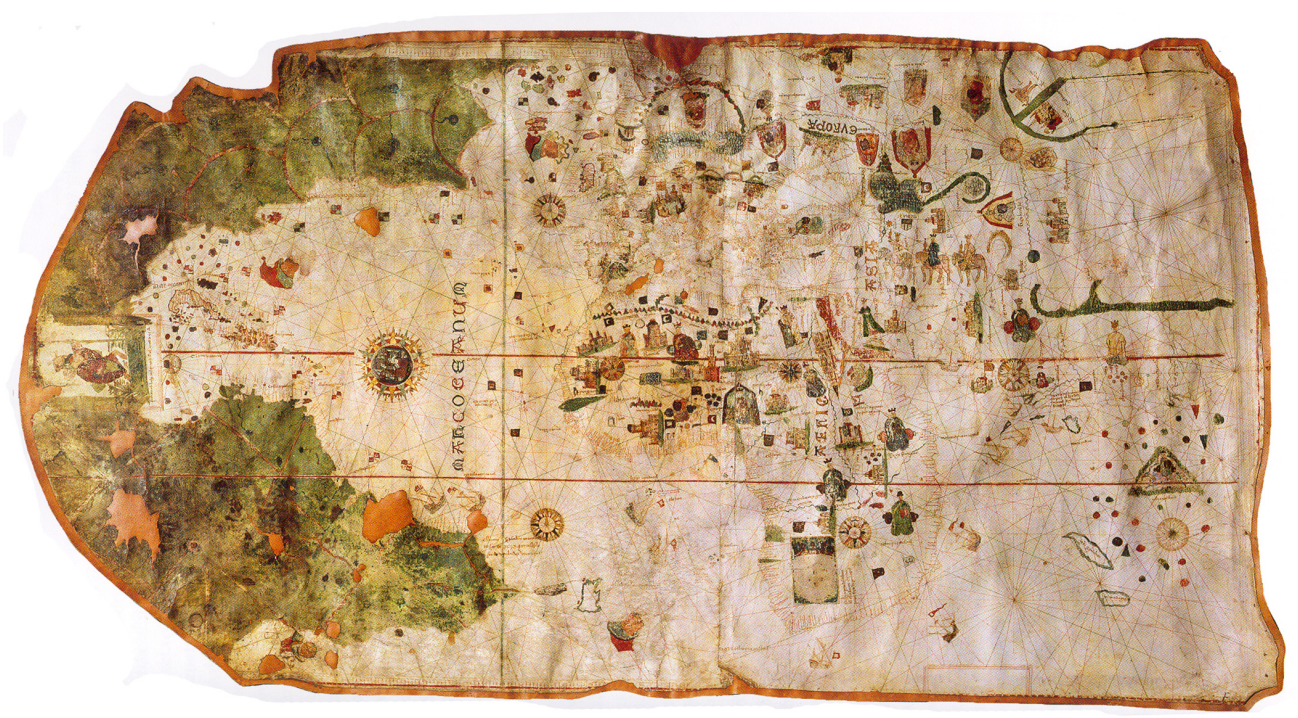

Note: This is considered the first world map that includes America. It is $93 \mathrm{~cm}$ high and $183 \mathrm{~cm}$ wide. It was made by Juan de la Cosa in 1500. Since the nineteenth century it has formed part of the collections of the Naval Museum of Madrid (Spain).

Map 2: Map of Gerardus Mercator. 1569

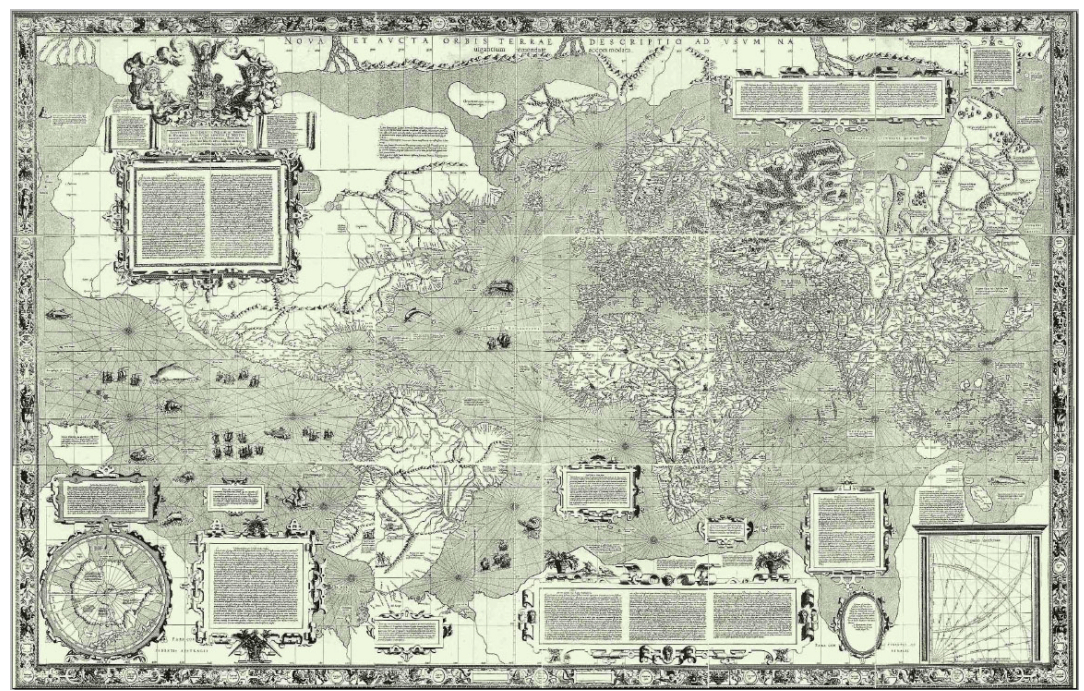

Note: This map was titled Nova et Aucta Orbis Terrae Descriptio ad Usum Navigantium Emendate Accommodata. It was made by Gerardus Mercator in 1569. Several hundred copies were printed, but only a handful survive. It was one of the first efforts to integrate the tradition of world map cartographers with the more accurate practical charts of sailors. It became the basis of posterior cartography until modern times. 
Map 3: Global silver flows. Yearly average. Metric tones. 1650-1750

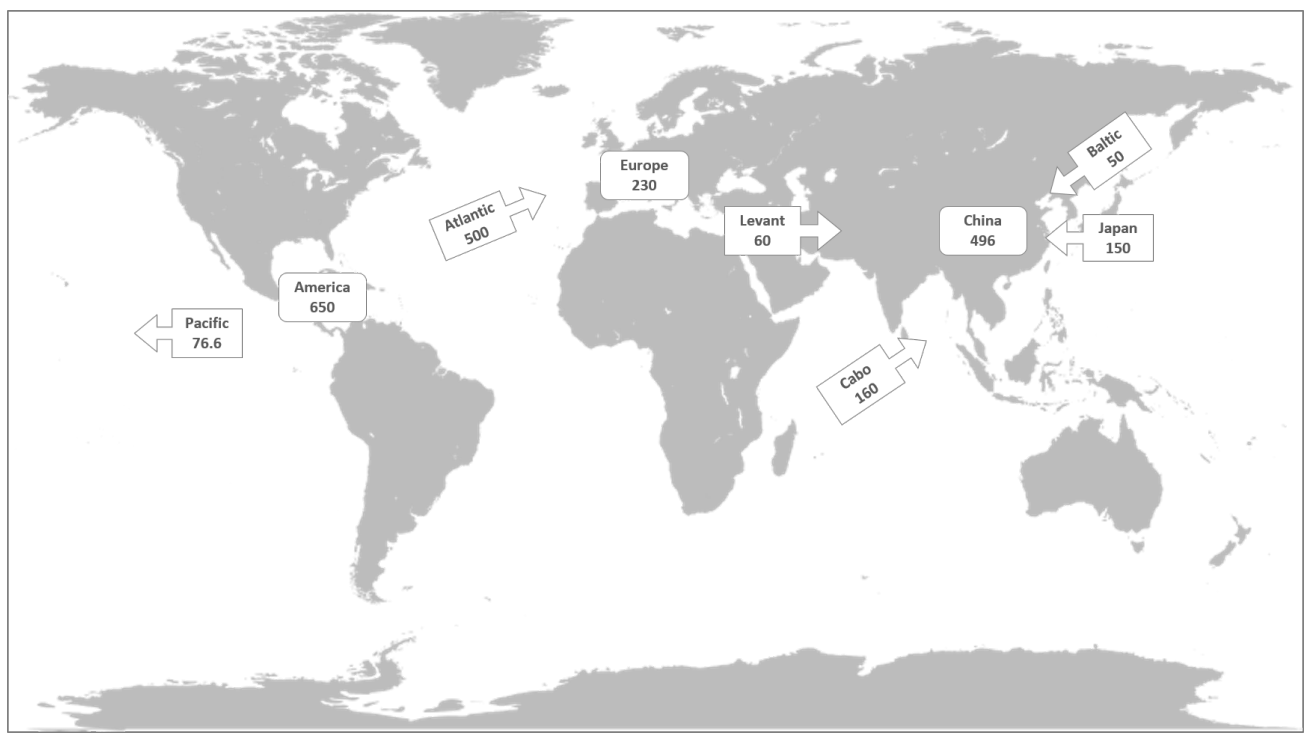

Note: This map shows the approximate average flow of silver in the world in the late 17 th and early 18 th century. It is based on Bonialian (2012) and Von Glahn (1996b).

Map 4: New Granada map. 1816

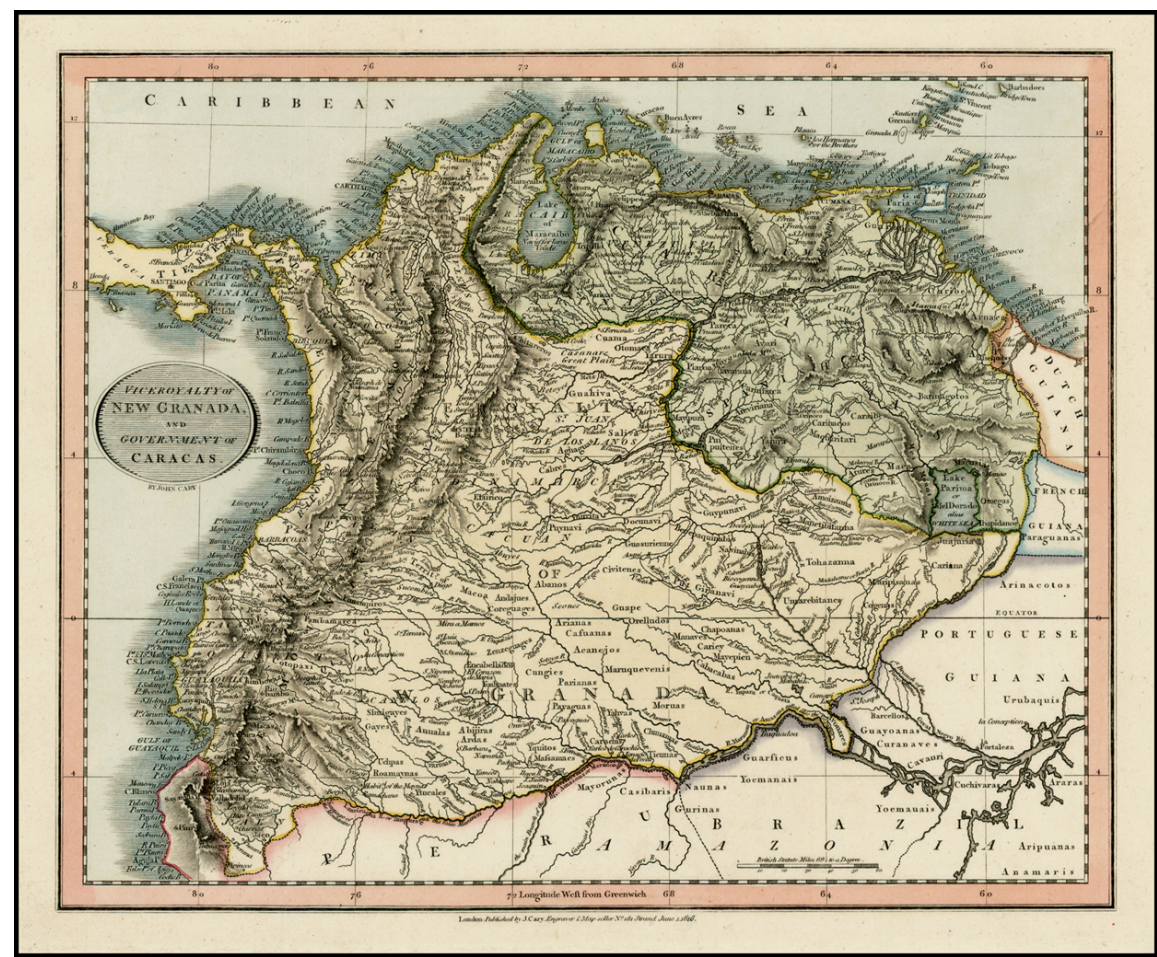

Note: This map was titled Viceroyalty of New Granada, and Governments of Caracas. It was published in an Atlas by John Cary in 1816. It includes information on islands, towns, rivers, mountains, and lakes. 
Map 5: Spanish Settlements in New Granada. 1500-1600

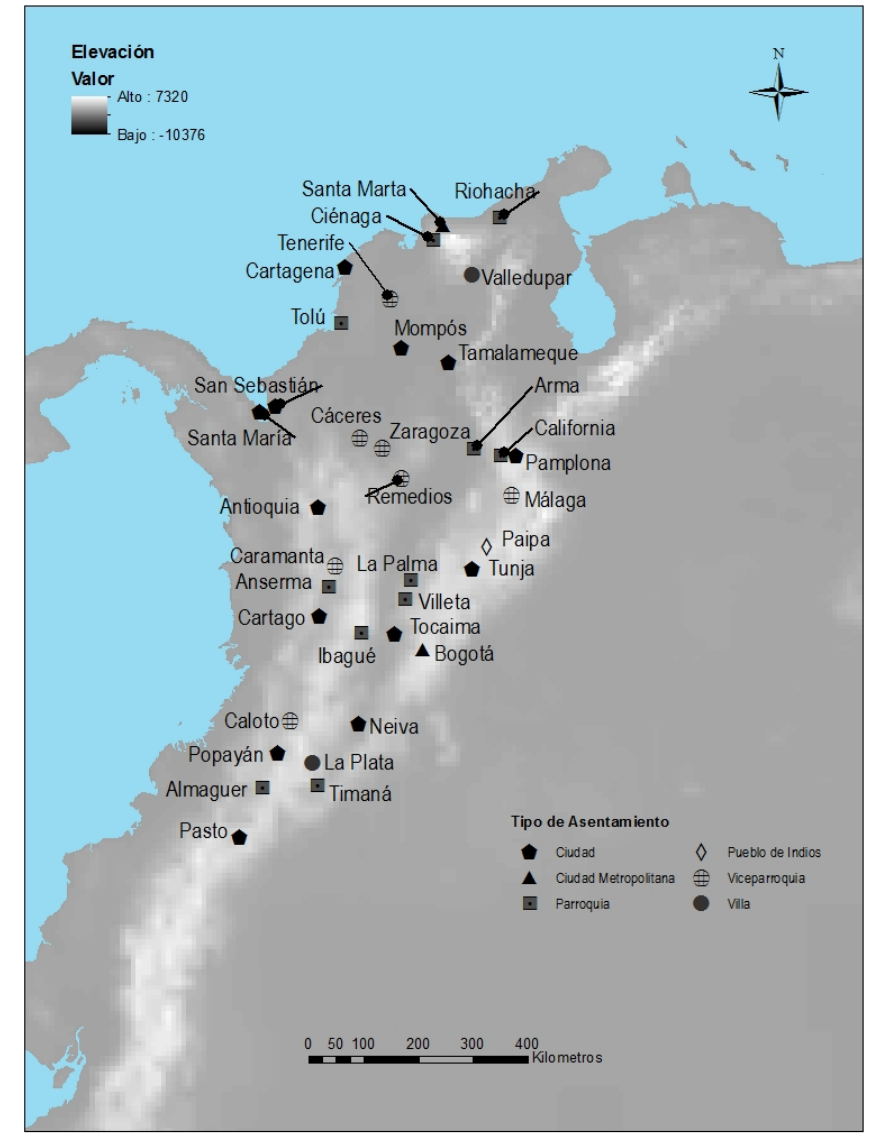

Note: This map shows the location of Spanish settlements in New Granada during the early colonial period. It categorizes the settlements by type and the territory by altitude. This map comes from (Mejía, 2016). 


\section{Tables}

Table 1: Transport Costs in Latin America c. 1840. Sterling per Ton

\begin{tabular}{lcc}
\hline & $\begin{array}{c}\text { Average freight } \\
\text { from England }\end{array}$ & $\begin{array}{c}\text { Internal transport cost } \\
\text { from port to capital }\end{array}$ \\
\hline Peru & 4 & 1.1 \\
Mexico & 2.5 & 15.4 \\
Uruguay & 2 & 0 \\
New Granada & 2.5 & 50.4 \\
Bolivia & 4.5 & 21.6 \\
Ecuador & 4.5 & 16.8 \\
Chile & 3.75 & 2.7 \\
Argentina & 2 & 0 \\
Venezuela & 3 & 4.8 \\
\hline
\end{tabular}

Note: This table presents the average transport cost of one ton for several Latin American countries in Pound Sterling. This table comes from de la Escosura 2009). 


\section{Illustration}

Illustration 1: Etching: Monte de la Agonía

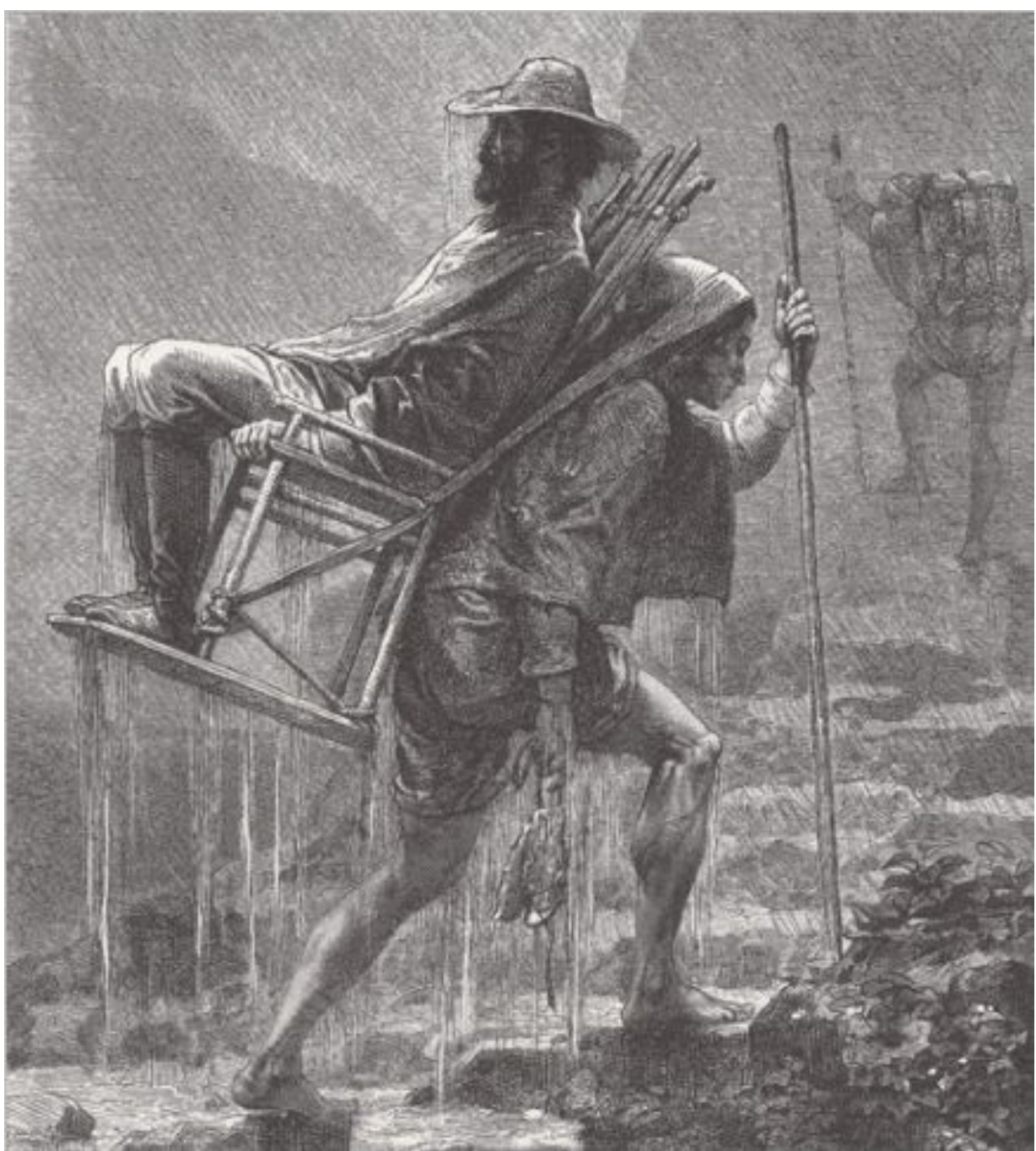

Source: This image is an etching published as complement of narratives made by French travelers to New Granada in the late 19th century. This image, in particular, depicts the crossing of the Andes (André and Saffray, 1879). 
Illustration 2: Etching: Puente sobre el Río Mayo

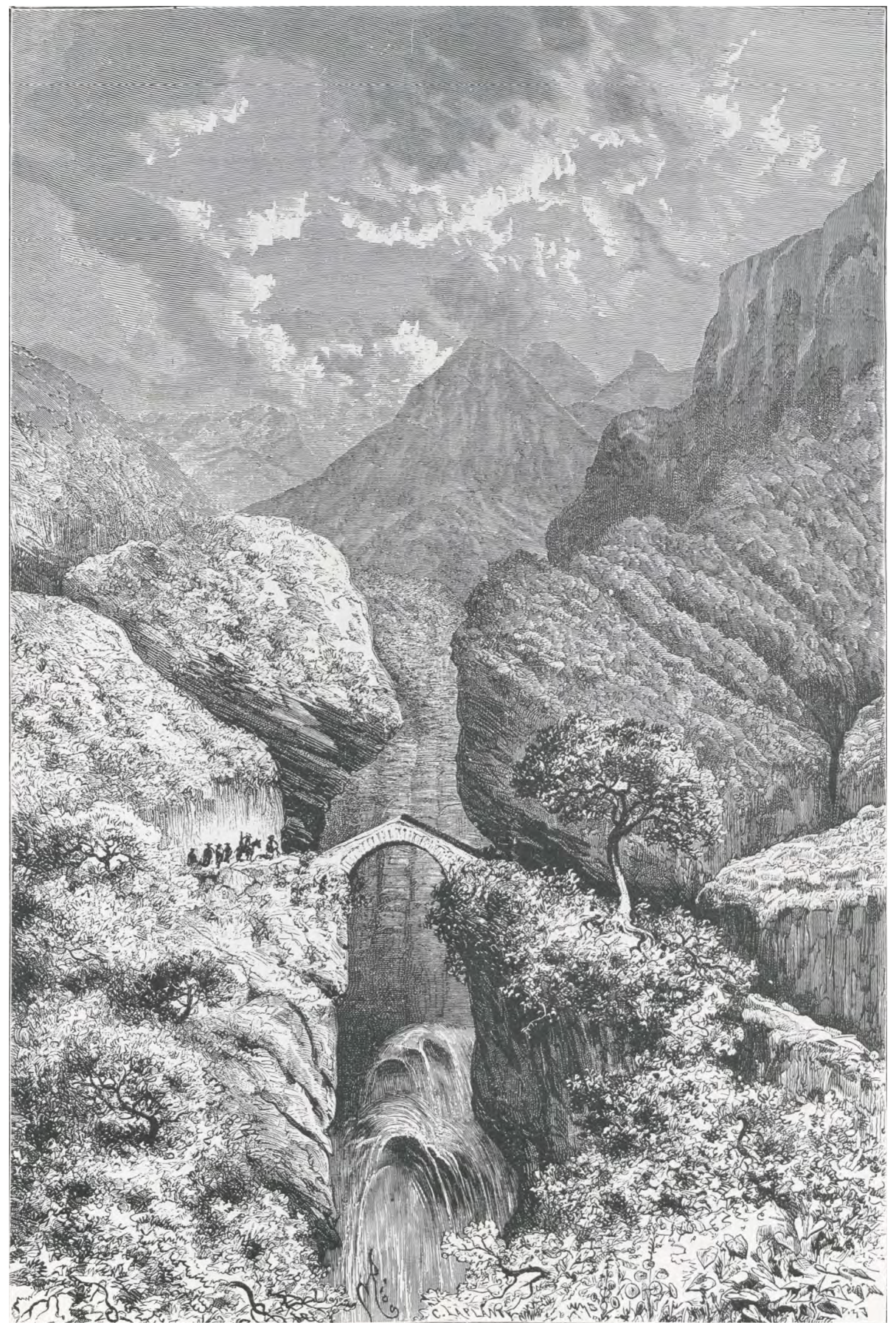

Note: This image is an etching published as complement of narratives made by French travelers to New Granada in the late 19th century. This image, in particular, depicts the crossing of a river in Cauca (André and Saffray, 1879). 


\section{Appendix: History from an economics perspec- tive}

This essay does not go into the details of what "an economics approach to history" is. Doing so would imply a deep reflection on a fairly extensive research field. However, in this section, I offer a brief idea, and some references, for those interested in digging into the subject.

To begin with, there is not a unified approach in economics for studying history-from now on, economic history. Mejía (2015) considers four agendas with different interest and methods (see Figure A1). In addition, several authors, including Mokyr (2010), Abramitzky (2015), and (Margo, 2018), show that economic history is an active field in permanent evolution, which feeds from the each time more diverse discipline of modern economics.

Illustration A1: Firm size and year of foundation. Industrial firms in Antioquia. Histogram

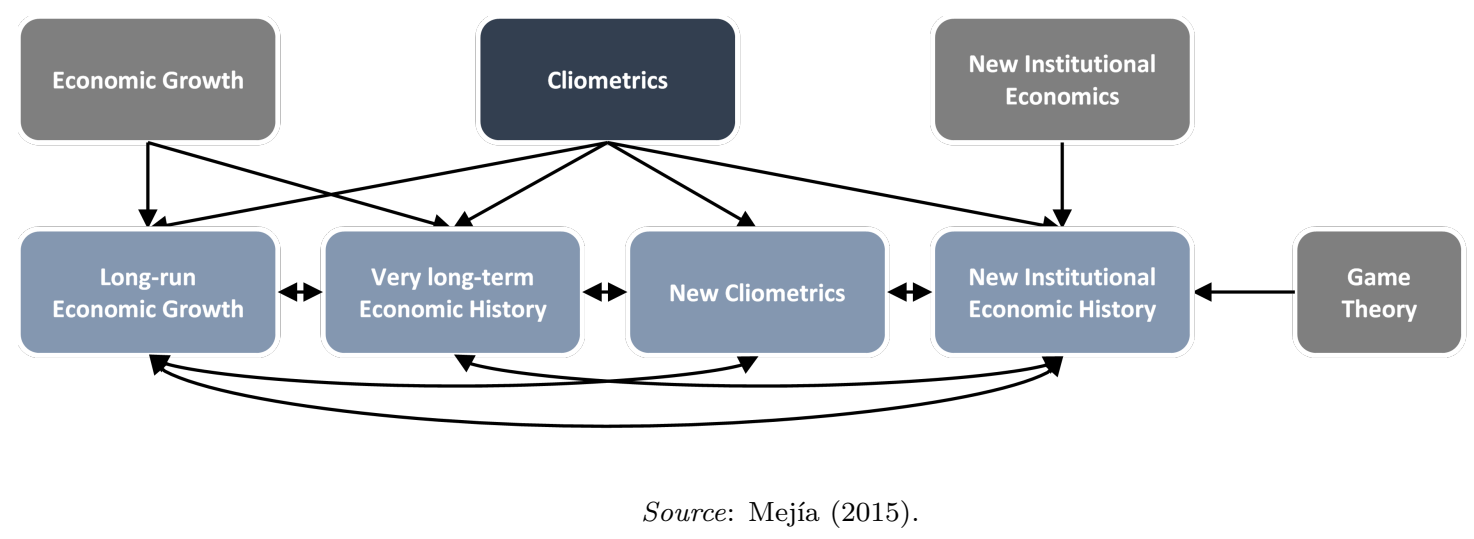

In any case, all the four agendas that compose economic history share roots in the neoclassical principles of mainstream economics. Following Colander (2000), we can consider six of those principles: $i$ ) to focus on allocation of resources at a given moment in time; ii) to accept some variation of utilitarianism as playing a central role in understanding the economy; iii) to focus on marginal trade-offs; $i v$ ) to assume farsighted rationality; $v$ ) to accept methodological individualism; vi) to follow a general equilibrium conception of the economy. Therefore, economic history is supported in a tradition that considers a valid interpretation of human behavior throughout space and time. This is a clear distinction from approaches in history, which usually emphasize 
the uniqueness of places and historical periods. What this essay uses as economics approach is nothing different that a practical implementation of these principles. 